\title{
Re-evaluation of Culture Condition of PC12 and SH-SY5Y Cells Based on Growth Rate and Amino Acid Consumption
}

\author{
HIROSHI SAKAGAMI ${ }^{1}$, RYUICHIRO SUZUKI ${ }^{2}$, YOSHIAKI SHIRATAKI ${ }^{2}$, SOICHI IWAMA ${ }^{3}$, MIKA NAKAGAWA ${ }^{3}$, \\ HAYATO SUZUKI ${ }^{3}$, KENTA TANAKA ${ }^{3}$, NOBUAKI TAMURA ${ }^{3}$ and HIROSHI TAKESHIMA ${ }^{3}$ \\ ${ }^{1}$ Meikai University Research Institute of Odontology (M-RIO), Saitama, Japan; \\ ${ }^{2}$ Faculty of Pharmacy and Pharmaceutical Sciences, Josai University, Saitama, Japan; \\ ${ }^{3}$ Division of Geriatric Dentistry. Meikai University School of Dentistry, Saitama, Japan
}

\begin{abstract}
Background/Aim: Most of the previous investigators have used various types of media for the culture of nerve cells. In order to optimize the culture conditions, we compared the growth rate and amino acid consumption by two popular neuron models, rat PC12 and human SH-SY5Y, grown in DMEM or DMEM: Ham's F-12 (1:1): non-essential amino acids, supplemented with $10 \%$ fetal bovine serum (referred to DMEM and Mix, respectively). Materials and Methods: Cell growth was monitored by the MTT method. Amino acids in the culture medium were quantitated by amino acid analysis after deproteinization. Results: Efficient cell attachment could be achieved even if PC12 cells were inoculated at extreme lower cell density in a non-coated plain dish, without addition of its condition medium. Both PC12 and SH-SY5Y cells proliferated up to slightly higher cell density in DMEM than in Mix. Approximately 2-fold higher utilization rate of glutamine and essential amino acids was observed in DMEM. Amyloid peptides such as $A \beta_{1-42}$ and $A \beta_{25-35}$ suppressed their growth nearly by $50 \%$. Conclusion: The present study suggests the usefulness of DMEM for the study of searching neuroprotective substances, based on its favorable effects on cell attachment, cell growth and amino acid utilization as well as amyloid peptide sensitivity.
\end{abstract}

This article is freely accessible online.

Correspondence to: Hiroshi Sakagami, Meikai University Research Institute of Odontology (M-RIO), Meikai University School of Dentistry, Sakado, Saitama 350-0283, Japan. Tel: +81 492792758, Fax: +81492855171, e-mail: sakagami@dent.meikai.ac.jp; Ryuichiro Suzuki, Faculty of Pharmacy and Pharmaceutical Sciences, Josai University, Sakado, Saitama, 350-0295, Japan. Tel/Fax: +81 492718089, e-mail: ryu_suzu@josai.ac.jp

Key Words: Nerve cell, culture condition, growth, amino acid consumption, amyloid peptide.
Due to the recent improvement of living environment and heath care systems, our life expectancy has been significantly prolonged, but in turn accompanied by increasing incidence of chronic diseases such as dementia (1-3). In order to spend a comfortable life, the onset of cerebral function disorders should be prevented or delayed. Alzheimer's disease (AD), the most common form of dementia, is characterized by the accumulation of amyloid- $\beta(\mathrm{A} \beta)$ in the brain. Cognitive behavioral therapy may be efficacious in ameliorating the development of Alzheimer's disease (AD), by preventing the accumulation of $A \beta$ (4). Considering the side-effects of inhibitors of secretases that block the initial steps of $\mathrm{A} \beta$ production, the prevention of early $\mathrm{A} \beta$ oligomerization seems to be more promising (5). As models of neurons, rat PC12 pheochromocytoma cells (6) and human SH-SY5Y neuroblastoma cells $(7,8)$ have been used by many investigators to search for neuroprotective substances. However, the composition of the culture media they have used is quite different from researcher to researcher: RPMI1640 (differentiated PC12) (9, 10), RPMI (PC12) (11), DMEM (PC12) (12, 13), DMEM (SH-SY5Y) (14), DMEM/Ham's F-12 (1:1) (SHSY 5Y) (15, 16), MEM/F-12 (SY-SY5Y) (17) and DMEM/F-12 + non-essential amino acids (SH-SY5Y) (18), all supplemented with serum and antibiotics. It is not clear why the inclusion of F-12 and non-essential amino acids is necessary to culture SH-SY5Y cells. As far as we know, there is no literature investigating the relationship between the growth and amino acid consumption in PC12 or SH-SY5Y cells.

In the present study, we compared the growth curve of PC12 and SY-5YSY cells in the following two media: (i) DMEM supplemented with $10 \%$ fetal bovine serum (FBS) (referred to as DMEM), and (ii) DMEM and HAM's F-12 supplemented with $10 \%$ FBS and non-essential amino acids (referred to as Mix). 


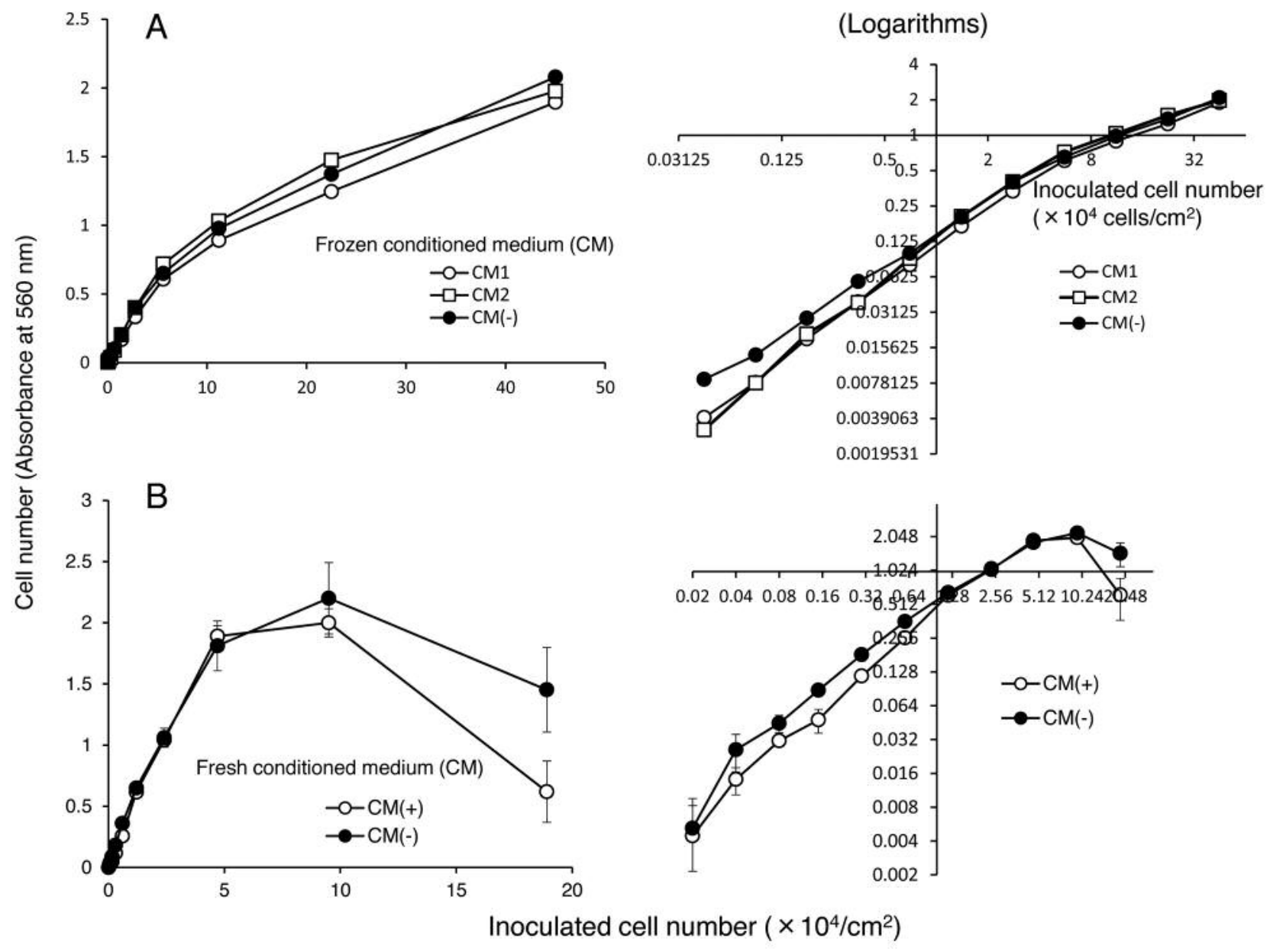

Figure 1. Effect of frozen (A) or freshly prepared (B) conditioned medium of PC12 cells on cell attachment. The cells at the indicated cell density were inoculated without $(\bullet)$ or with $(\bigcirc, \square) 50 \%$ conditioned medium, and incubated for 48 hours to determine the attached cell number by MTT method. Each value represents mean \pm S.D. of triplicate assay. Right panels are the logarithms of the corresponding left panels.

\section{Materials and Methods}

Materials. The following chemicals and reagents were obtained from the indicated companies: Dulbecco's modified Eagle's medium (DMEM), Ham's F-12 (with glutamine and phenol red), MEM, nonessential amino acid, trichloroacetic acid (TCA), dimethyl sulfoxide (DMSO) (Wako Pure Chemical Ind., Ltd., Osaka, Japan); fetal bovine serum (FBS), 3-(4,5-dimethylthiazol-2-yl)-2,5-diphenyltetrazolium bromide (MTT) (Sigma-Aldrich Inc., St. Louis, MO, USA); $\mathrm{A} \beta_{1-42}$ and $\mathrm{A} \beta_{25-35}$ (Peptide Institute Inc., Osaka, Japan); Culture plastic dishes and plates (96-well, 24-well) were purchased from TrueLine (Nippon Genetics Co., Ltd, Tokyo, Japan) and Becton Dickinson (Franklin Lakes, NJ, USA, respectively).

Cell culture. PC12, a cell line derived from a pheochromocytoma of the rat adrenal medulla (6), and SH-SY5Y, cloned from a human bone marrow biopsy derived line called SK-N-SH $(7,8)$ were purchased from Riken Cell Bank (Tsukuba, Japan). These cells were cultured in DMEM or Mix.
Determination of viable cell number. The culture medium was removed, and replaced with fresh medium containing $0.2 \mathrm{mg} / \mathrm{ml}$ MTT. Cells were incubated for $2 \mathrm{~h}$, and the formazan precipitate was dissolved in DMSO to measure the absorbance at $560 \mathrm{~nm}$ with a plate leader (Infinite F 50 R, TECAN, Kawasaki, Japan). The compound concentration that reduced the viable cell number by $50 \%\left(\mathrm{CC}_{50}\right)$ was determined from the dose-response curve, with triplicate assays (19).

Amino acid determination. Culture supernatant $(100 \mu \mathrm{M})$ was mixed with $10 \%$ TCA, and placed for $10 \mathrm{~min}$ on ice. After centrifugation at $10,000 \times g$, the deproteinized supernatant was frozen at $-30^{\circ} \mathrm{C}$ prior to amino acid analysis with amino acid analyzer (JLC-500/V) in analytical center, Josai University (20).

Statistical treatment. Experimental values are expressed as the mean \pm standard deviation (SD) of triplicate or quadruplicate samples. Statistical analysis was performed by using Student's $t$ test. A $p$-value $<0.05$ was considered to be significant. 


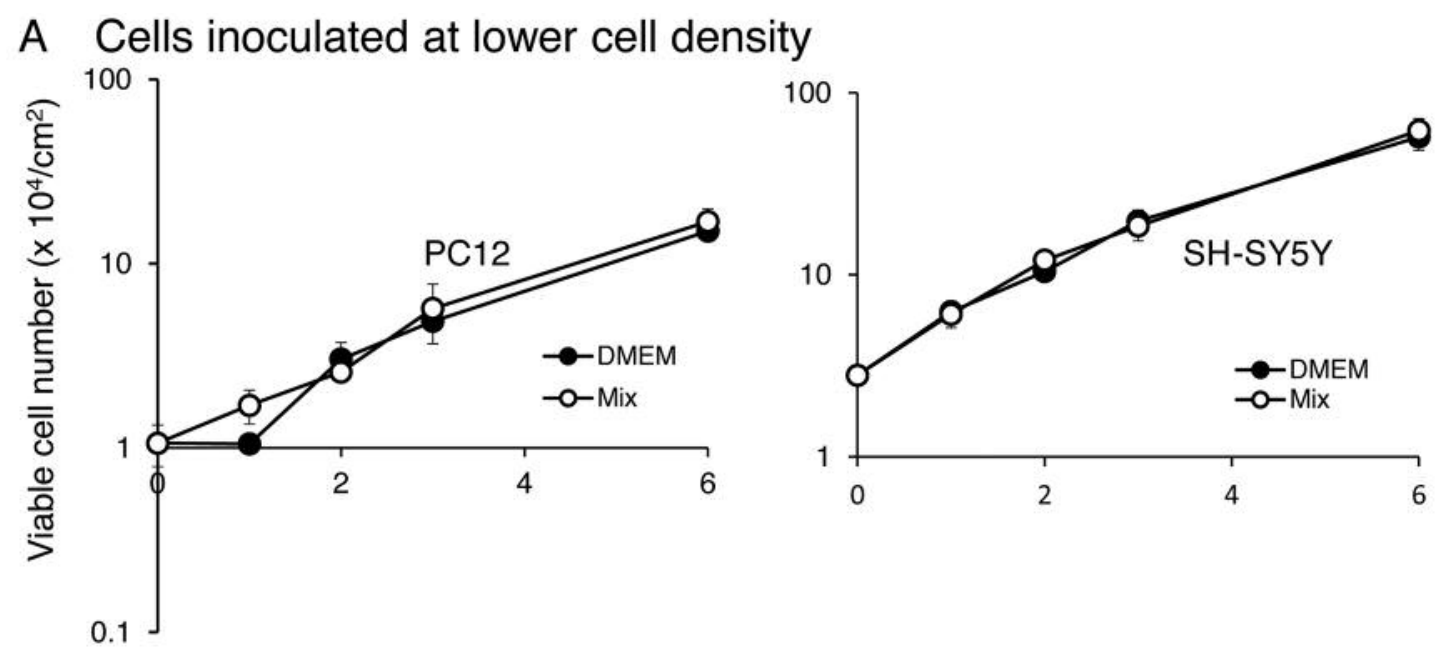

\section{B Cells inoculated at higher cell density}
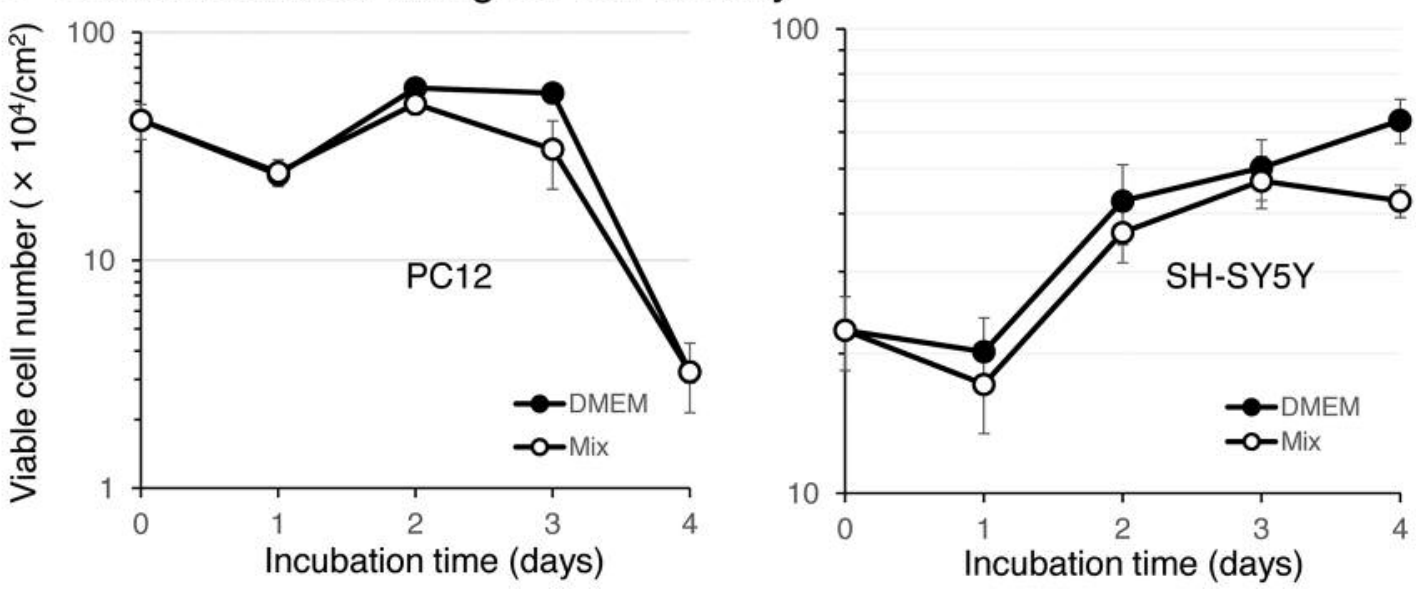

Figure 2. Growth curve of PC12 (left panel) and SH-SY5Y cells (right panel) inoculated at lower (A) or higher (B) cell density in DMEM (๑) or Mix (○). Medium was replaced by fresh medium at day 3 (A). Each value represents mean \pm S.D. of triplicate assay.

\section{Results}

Effect of conditioned medium on cell attachment. When PC12 and SH-SY5Y cells were inoculated at low cell density and incubated for long periods, PC12 cells, but not $\mathrm{SH}-$ SY5Y cells, formed a clusters. There was a possibility that conditioned culture medium of $\mathrm{PC} 12$ cells may have stimulated their growth. This possibility, however, was eliminated by our finding that the growth of PC12 cells was not stimulated by the addition of either frozen (A) or fresh (B) conditioned medium (Figure 1).

Effect of the inoculated number of cells on cell attachment. When the attached cell number (indicated by absorbance at $560 \mathrm{~nm}$ ) in log scale was plotted as a function of cell number in log scale, a straight line was produced at a lower cell density range (right panel in Figure 1A and B). This indicates complete cell attachment that can be achieved even if PC12 cells were inoculated at extremely low cell density in plain 96-microwell plates, without coating with collagen or lysine.

Comparison between two culture media in promoting cell growth. When PC12 (left panel) and SH-SY5Y cells (right panel) were inoculated at a low density (1.06 and $2.8 \times 10^{4} / \mathrm{cm}^{2}$, respectively), the cell number continued to grow during 6 days of culture (Figure 2A). Their proliferation curves were nearly superimposable with each other, regardless of the type of culture medium: either DMEM or Mix (Figure 2A). 


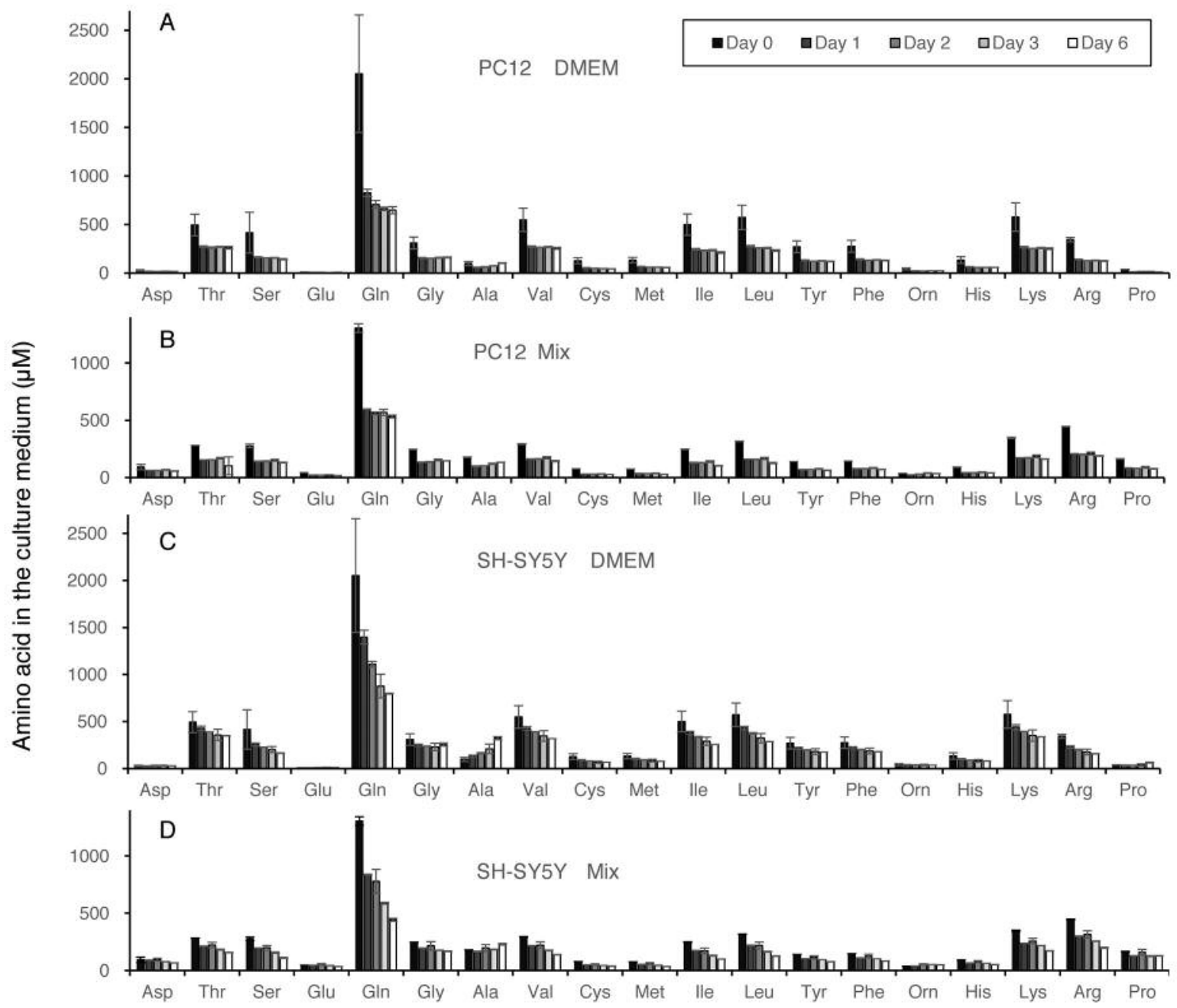

Figure 3. Amino acid concentrations in the medium of PC12 or SH-SY5Y cells after 0, 1, 2, 3 or 6 days after inoculation at lower cell density. Medium was prepared as described in Figure $2 A$. Each value represents mean $\pm S . D$. of triplicate assay.

When PC12 (left panel) and SH-SY5Y cells (right panel) were inoculated at a high density $\left(41.13\right.$ and $22.45 \times 10^{4} / \mathrm{cm}^{2}$, respectively), the cell number only slightly increased for the first 3 days, followed by a rapid decline of viability (Figure 2B). The use of DMEM rather than the Mix sustained higher cell viability (Figure $2 \mathrm{~A})$.

Amino acid consumption during culture. Changes of extracellular amino acid concentration during culture of PC12 and SH-SY5Y cells inoculated at low or high cell density are shown in Figure 3 (calculated in Exp. I of Table I) and Figure 4 (calculated in Exp. II of Table I), respectively. Amino acids are listed in the order of elution. Both cells utilized glutamine more efficiently than nine essential amino acids (threonine, valine, methionine, isoleucine, leucine, phenylalanine, histidine, lysine, arginine). Amino acid utilization by both $\mathrm{PC} 12$ and $\mathrm{SH}-$ SY5Y cells grown in DMEM was nearly twice as much as higher than that grown in Mix, regardless of cell density (Table I). All amino acids were not exhausted during the culture periods. When cells reached confluency, significant amounts of alanine accumulated in the medium.

Sensitivity of cells to amyloid peptides. The cells grown in DMEM were sensitive to two amyloid peptides, $A \beta_{1-42}$ and $\mathrm{A} \beta_{25-35}$. When PC12 and SH-SY5Y cells were exposed to amyloid peptides for $48 \mathrm{~h}$, their viability declined to nearly half of the control (Figure 4). The optimal concentrations of $\mathrm{A} \beta_{1-42}$ (A) and $A \beta_{25-35}$ (B) were 0.063 and $0.63 \mu \mathrm{M}$, respectively (Figure 4). 

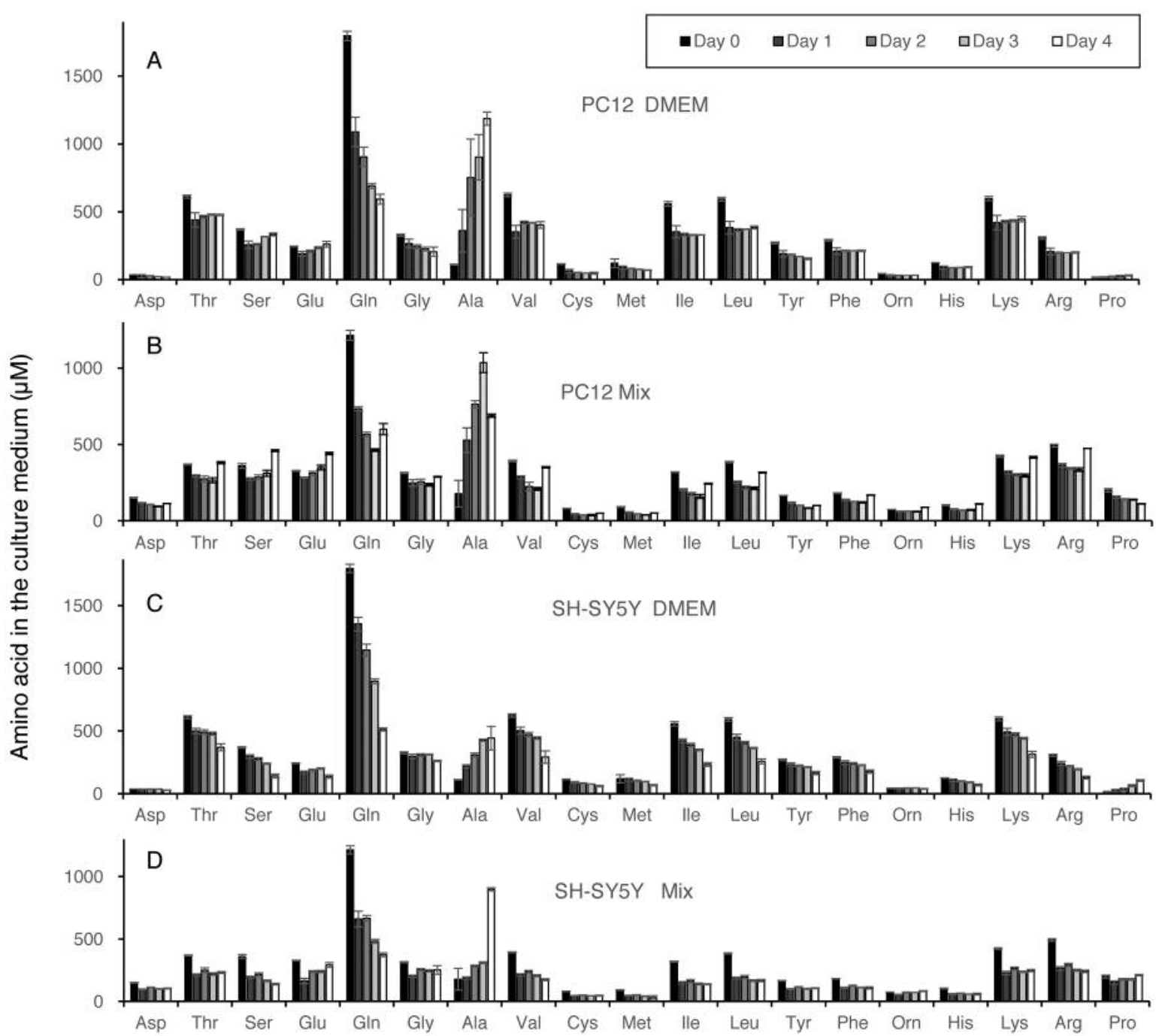

Figure 4. Amino acid concentrations in the medium of PC12 or SH-SY5Y cells after 0, 1, 2, 3 or 4 days after inoculation at higher cell density. Medium was prepared as described in Figure $2 B$. Each value represents mean \pm S.D. of triplicate assay.

\section{Discussion}

The present study demonstrated that the growth of both PC12 and SH-SY5Y cells was superior in DMEM than in Mix, and that their consumption rate of glutamine and nine essential amino acids in DMEM was nearly two-fold in that observed in Mix (Table I). Since all amino acids remained at more than $30 \%$ of the initial value at the confluent phase, growth cessation at higher cell density seems not to be due to the exhaustion of essential amino acids. Efficient cell attachment could be achieved even if $\mathrm{PC} 12$ cells were inoculated at a lower cell density (as low as $200 \mathrm{cells} / \mathrm{cm}^{2}$ ) in plain dish (not coated with collagen nor lysine), without addition of conditioned medium. We also found that treatment of amyloid peptides such as $A \beta_{1-42}$ and $A \beta_{25-35}$, nearly halved cell viability. The extent of sensitivity to amyloid peptides was similar to that of previously published values $(9,11,12,13,15,18)$. These evidence suggests that the use of DMEM (supplemented with 10\%FBS and antibiotics) is the best culture medium for both PC12 and SH-SY5Y cells. Extensive searches of neuroprotective substances using this culture system are underway in our laboratory.

We also found that alanine accumulated up to $1 \mathrm{mM}$, when cells became confluent and stopped proliferation. It has been reported that elevation of alanine/serine over $4 \mathrm{mM}$ induced the production of cytotoxic 1-deoxysphingolipids (21). Further metabolic studies are required to test the 
in vivo $31: 1089-1095(2017)$

Table I. Amino acid consumption of PC12 and SH-SY5Y cells that had been inoculated at lower (Exp. 1) or higher cell density (Exp. II) in DMEM or Mix. Each value was calculated using the data of Figures 3 and 4, respectively.

Changes in concentrations $(\mu \mathrm{M})$

\begin{tabular}{|c|c|c|c|c|c|c|c|c|c|c|c|c|}
\hline & \multicolumn{8}{|c|}{ Exp. I } & \multicolumn{4}{|c|}{ Exp. II } \\
\hline & \multicolumn{4}{|c|}{$\mathrm{PC} 12$} & \multicolumn{4}{|c|}{ SH-SY5Y } & \multirow{2}{*}{\multicolumn{2}{|c|}{$\begin{array}{c}\text { PC12 } \\
\text { Days 0-4 }\end{array}$}} & \multirow{2}{*}{\multicolumn{2}{|c|}{$\begin{array}{c}\text { SH-SY5Y } \\
\text { Days 0-4 }\end{array}$}} \\
\hline & \multicolumn{2}{|c|}{ Days 0-3 } & \multicolumn{2}{|c|}{ Days 3-6 } & \multicolumn{2}{|c|}{ Days 0-3 } & \multicolumn{2}{|c|}{ Days 3-6 } & & & & \\
\hline & DMEM & Mix & DMEM & Mix & DMEM & Mix & DMEM & Mix & DMEM & Mix & DMEM & $\operatorname{Mix}$ \\
\hline Asp & -10 & -25 & -13 & -35 & 1 & -17 & 0 & -27 & -19 & -38 & -9 & -48 \\
\hline Thr & -226 & -114 & -233 & -179 & -137 & -100 & -146 & -125 & -133 & 12 & -240 & -138 \\
\hline Ser & -258 & -125 & -272 & -146 & -213 & -120 & -251 & -167 & -37 & 100 & -228 & -221 \\
\hline Glu & -4 & -30 & -2 & -28 & 4 & -4 & 4 & -11 & 17 & 114 & -107 & -35 \\
\hline Gln & -1393 & -737 & -1405 & -773 & -1176 & -719 & -1257 & -865 & -1204 & -614 & -1284 & -840 \\
\hline Gly & -150 & -93 & -147 & -102 & -79 & -71 & -53 & -79 & -121 & -25 & -65 & -62 \\
\hline Ala & -24 & -58 & 5 & -44 & 112 & 5 & 225 & 50 & 1076 & 510 & 333 & 719 \\
\hline Val & -280 & -119 & -294 & -148 & -201 & -119 & -229 & -155 & -221 & -42 & -332 & -219 \\
\hline Cys & -80 & -46 & -83 & -50 & -59 & -34 & -59 & -40 & -67 & -32 & -54 & -35 \\
\hline Met & -72 & -37 & -76 & -45 & -49 & -29 & -55 & -41 & -50 & -40 & -51 & -59 \\
\hline Ile & -263 & -108 & -287 & -143 & -209 & -119 & -243 & -149 & -228 & -76 & -325 & -181 \\
\hline Leu & -313 & -150 & -342 & -190 & -249 & -154 & -285 & -192 & -208 & -68 & -334 & -218 \\
\hline Tyr & -145 & -64 & -151 & -77 & -89 & -47 & -95 & -65 & -117 & -66 & -105 & -60 \\
\hline Phe & -140 & -61 & -145 & -73 & -89 & -44 & -95 & -64 & -78 & -13 & -115 & -72 \\
\hline Orn & -18 & 2 & -20 & -2 & -5 & 14 & -7 & 10 & -12 & 14 & -5 & 8 \\
\hline $\mathrm{His}$ & -75 & -46 & -76 & -51 & -52 & -30 & -53 & -42 & -33 & 7 & -55 & -45 \\
\hline Lys & -317 & -161 & -326 & -186 & -225 & -130 & -238 & -175 & -152 & -7 & -283 & -175 \\
\hline Arg & -214 & -236 & -219 & -257 & -168 & -191 & -185 & -249 & -106 & -19 & -177 & -252 \\
\hline Pro & -24 & -75 & -28 & -87 & 0 & -39 & 25 & -36 & 17 & -121 & 91 & 11 \\
\hline
\end{tabular}
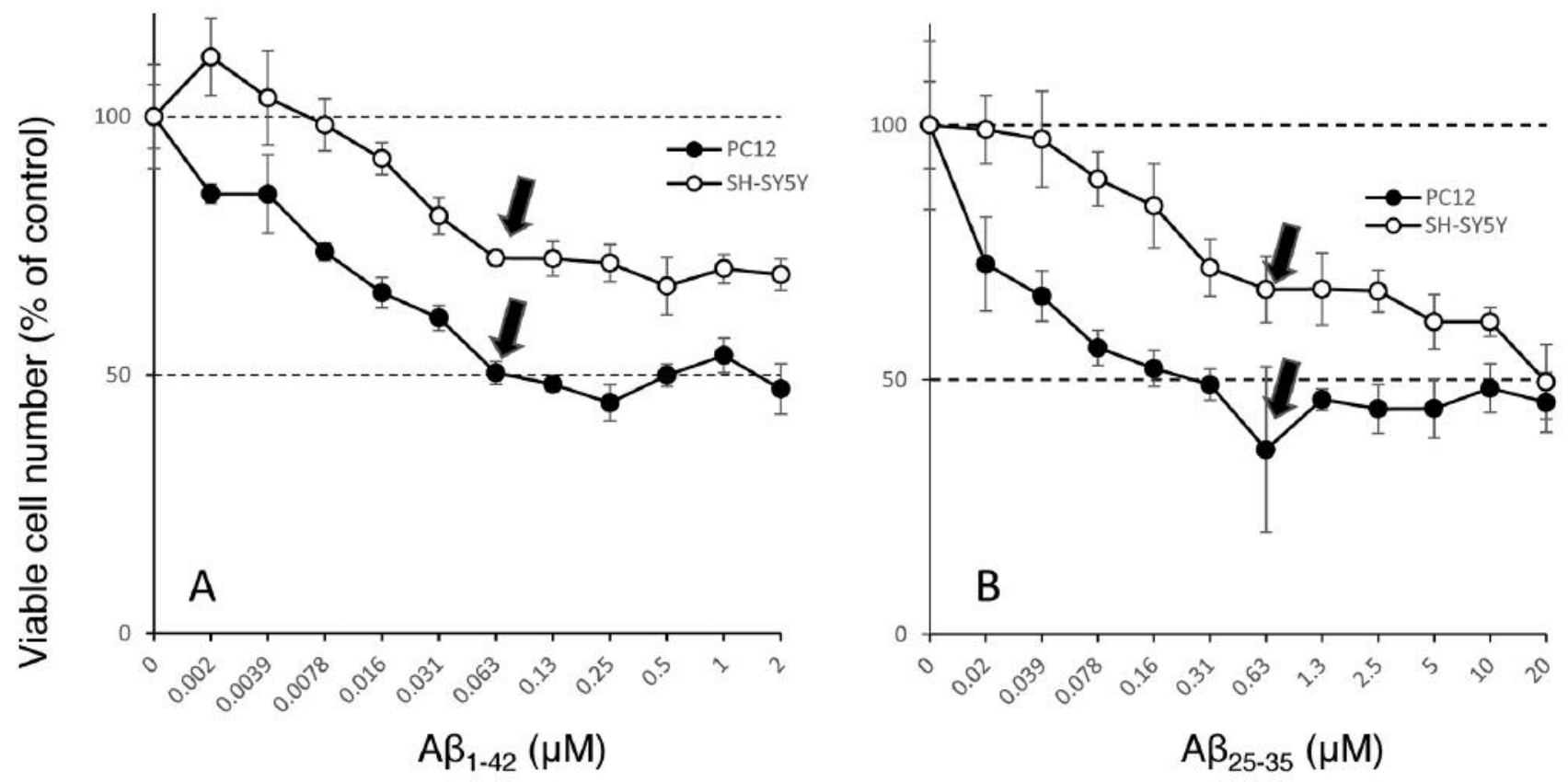

Figure 5. Effect of $A \beta_{1-42}(A)$ and $A \beta_{25-35}(B)$ on the viable cell number of PC12 (৩) or SH-SY5Y (○) cells. Each value represents mean $\pm S . D$. of quadruplicate assay. Arrow indicates the point where plateau phase of growth inhibition was reached. 
possibility whether the neurotoxicity at a higher cell density is associated with the changes in lipid metabolism.

\section{Conflicts of Interest}

There are no known conflicts of interest associated with this publication and there has been no significant financial support for this work that could have influenced its outcome.

\section{Acknowledgements}

This work was partially supported by KAKENHI from the Japan Society for the Promotion of Science (JSPS) (PI: Sakagami H, No., 16K11519).

\section{References}

1 Parra-Vidales E, Soto-Pérez F, Perea-Bartolomé MV, FrancoMartín MA and Muñoz-Sánchez JL: Online interventions for caregivers of people with dementia: a systematic review. Actas Esp Psiquiatr 45(3): 116-126, 2017.

2 Ostan R, Monti D, Gueresi P, Bussolotto M, Franceschi C and Baggio G: Gender, aging and longevity in humans: an update of an intriguing/neglected scenario paving the way to a genderspecific medicine. Clin Sci (Lond) 130(19): 1711-1725, 2016.

3 Kroneman M, Boerma W, van den Berg M, Groenewegen P, de Jong $\mathrm{J}$ and van Ginneken E: Netherlands: Health System Review. Health Syst Transit 18(2): 1-240, 2016.

4 Reid LD, Avens FE and Walf AA: Cognitive behavioral therapy (CBT) for preventing Alzheimer's disease. Behav Brain Res 334: 163-177, 2017.

5 Parsons CG and Rammes G: Preclinical to phase II amyloid beta (A $\beta)$ peptide modulators under investigation for Alzheimer's disease. Expert Opin Investig Drugs 26(5): 579-592, 2017.

6 Greene LA and Tischler AS: Establishment of a noradrenergic clonal line of rat adrenal pheochromocytoma cells which respond to nerve growth factor. Proc Natl Acad Sci USA 73(7): 2424-2428, 1976

7 Biedler JL, Helson L and Spengler BA: Morphology and growth, tumorigenicity, and cytogenetics of human neuroblastoma cells in continuous culture. Cancer Res 33(11): 2643-2652, 1973.

8 Biedler JL, Roffler-Tarlov S, Schachner M and Freedman LS: Multiple neurotransmitter synthesis by human neuroblastoma cell lines and clones. Cancer Res 38: 3751-3757, 1978.

9 Xu P, Li Z, Wang H, Zhang X and Yang Z: Triptolide Inhibited cytotoxicity of differentiated PC12 cells induced by amyloidbeta $_{25-35}$ via the autophagy pathway. PLoS One 10(11): e0142719, 2015.

10 Tsai YC, Lee YM, Lam KK, Lin JF, Wang JJ, Yen MH and Cheng PY: The role of heat shock protein 70 in the protective effect of YC-1 on $\beta$-amyloid-induced toxicity in differentiated PC12 cells. PLoS One 8(7): e69320, 2013.
11 Muthaiyah B, Essa MM, Chauhan V and Chauhan A: Protective effects of walnut extract against amyloid- $\beta$ peptide-induced cell death and oxidative stress in PC12 cells. Neurochem Res 36(11): 2096-2103, 2011.

$12 \mathrm{Ma} \mathrm{R}$, Hu J, Huang C, Wang M, Xiang $\mathrm{J}$ and Li G: JAK2/STAT5/Bcl-xL signalling is essential for erythropoietinmediated protection against apoptosis induced in PC12 cells by the amyloid $\beta$-peptide $A \beta_{25-35}$. Br J Pharmacol 171(13): 32343245,2014

13 Ai Z, Li C, Li L and He G: Resveratrol inhibits $\beta$-amyloidinduced neuronal apoptosis via regulation of p53 acetylation in PC12 cells. Mol Med Rep 11: 2429-2434, 2015.

14 Hettiarachchi N, Dallas M, Al-Owais M, Griffiths H, Hooper N, Scragg J, Boyle J and Peers C: Heme oxygenase-1 protects against Alzheimer's amyloid- $\beta(1-42)$-induced toxicity via carbon monoxide production. Cell Death Dis 5: e1569, 2014.

15 Zhang Y, Jiao G, Song C, Gu S, Brown RE, Zhang J, Zhang P, Gagnon J, Locke S, Stefanova R, Pelletier C, Zhang Y and Lu $\mathrm{H}$ : An extract from shrimp processing by-products protects $\mathrm{SH}-$ SY5Y cells from neurotoxicity induced by $\mathrm{A} \beta_{25-35}$. Mar Drugs 15(3): 83, 2017.

16 Cameron RT, Quinn SD, Cairns LS, MacLeod R, Samuel ID, Smith BO, Carlos Penedo J and Baillie GS: The phosphorylation of Hsp20 enhances its association with amyloid- $\beta$ to increase protection against neuronal cell death. Mol Cell Neurosci 61: 4655, 2014.

17 Wang Q, Yu X, Patal K, Hu R, Chuang S, Zhang G and Zheng $\mathrm{J}$ : Tanshinones inhibit amyloid aggregation by amyloid- $\beta$ peptide, disaggregate amyloid fibrils, and protect cultured cells. ACS Chem Neurosci 4(6): 1004-1015, 2013.

18 Chilumuri A and Milton NG: The role of neurotransmitters in protection against amyloid- $\beta$ toxicity by KiSS-1 overexpression in SH-SY5Y neurons. ISRN Neurosci 2013: 253210, 2013.

19 Sakagami H, Uesawa Y, Ishihara M, Kagaya H, Kanamoto T, Terakubo S, Nakashima H, Takao K and Sugita Y: Quantitative structure-cytotoxicity relationship of oleoylamides. Anticancer Res 35: 5341-5355, 2015.

20 Tanaka S, Machino M, Akita S, Yokote Y and Sakagami H: Changes in salivary amino acid composition during aging. In Vivo 24: 853-856, 2010.

21 Esaki K, Sayano T, Sonoda C, Akagi T, Suzuki T, Ogawa T, Okamoto M, Yoshikawa T, Hirabayashi Y and Furuya S: LSerine deficiency elicits intracellular accumulation of cytotoxic deoxysphingolipids and lipid body formation. J Biol Chem 290(23): 14595-14609, 2015.
Received August 17, 2017

Revised September 7, 2017

Accepted September 8, 2017 